\section{Law and Literature in Dialogue}

\section{To THE EDITOR:}

I read Julie Stone Peters's "Law, Literature, and the Vanishing Real: On the Future of an Interdisciplinary Illusion" (120 [2005]: 442-53) with interest and a sense of recognition. Peters traces persuasively the history of the "law and literature" movement in its principal manifestations (humanism, hermeneutics, and narrative, in her formulation) and notes accurately that the forms of interdisciplinarity involved tended to caricature disciplinary difference "through each discipline's longing for something it imagined the other to possess." Or, in another striking summary: "each discipline came to desire in itself what the other discipline had put there" (449). This is true to my own experience of teaching law and literature.

And yet, Peters's focus on the "interdisciplinary phantasms" (448) evoked in attempts to cross between law and literature may obscure what seems to me the deeper raison d'être of the lawand-literature movement, for all its real incoherence and failure of definition. Let me try to put it this way: what if law and literature were not so much separate entities but rather twins separated at birth and seeking (with something of the melodrama such searches involve) to reunite? What really is at stake in law and lit-or let's say, more awkwardly but more accurately: law and the interpretive humanities-may be the claim of the law to institutional and educational autonomy. (The claim of literary study to autonomy would be equally questionable-but it's always been more tenuous.) That is to say: what if literature, and interpretive disciplines generally, harbored a kind of impensé of the law that had been suppressed, or repressed, in the course of its evolution?

It is arguable that law began as a rhetorical practice-rhetoric in ancient Athens was mainly about helping you make your case in courts of law or other public assemblies. But the law long since suppressed its rhetorical origins in favor of a claim to professional autonomy and a professionally hermetic language. Perhaps the process of disciplinary professionalization always entails a repression of rhetorical origins, which come to seem scarcely avowable as a foundation. Certainly legal studies in the United States over the course of their formation sought to divorce themselves from the rhetorical and oratorical tradition in order to claim professional authority and disciplinary independence. Law schools exist to teach students to "think like lawyers." While legal studies, like courts of law, often need to listen to testimony from fields outside, law nonetheless constantly asks: Is this relevant to the law? In what terms can the law use it? The law assigns its actors various gatekeeping functions to preserve its own nature and its autonomy.

To challenge that autonomy and the apparent security it brings with it is to hold the law accountable to the other interpretive disciplines. It is to challenge the implicit claim that legal terms of art-for instance, the language of "intent" or of "the will"-are self-definitional and off-limits to nonlegal questioners. Is the notion of human agency implicit in much legal language true to contemporary understandings of how people behave? Does it matter? Do legal opinions obscure something of importance in describing confessions under interrogation as the product of a "free and rational will"? Consider, as an extreme example of the law's attempt to keep its language to itself, the now infamous "Bybee Memo" of 1 August 2002, which has constant recourse to the dictionary-to various dictionaries, in fact-to produce definitions of "torture" so bizarre that even our administration has now reluctantly been forced to repudiate them (see Jay S. Bybee, "Memorandum for Alberto R. Gonzales, Counsel to the President, Re: Standards of Conduct for Interrogation under 18 U.S.C. $\$ \$ 2340-2340$ A," available at FindLaw [http://news.findlaw.com/hdocs/docs/ doj/bybee80102mem.pdf] and in The Torture Papers, ed. Karen J. Greenberg and Joshua L. Dratel [New York: Cambridge UP, 2005]; and see my comment, "The Plain Meaning of Torture," Slate 9 Feb. 2005, 28 July 2005 [http://www.slate .msn.com/id/2113314]).

I agree with Peters that we are "moving beyond [law and literature] as a cognizable interdisciplinary formation" (451). But I don't want to subscribe fully to her elegiac tone. If "law and literature" never quite delivered on its promise, there is still work to be done across that and. It's not that one discipline should invade and conquer the other or even wage unending guerrilla war within its territory. It's rather that hidden within 
all our disciplinary formations is some residue of what was repressed over the course of their history, and this residue may well contain something that could make a difference. It has mattered to literary study that it has been challenged by critics (often, to be sure, obtuse and ill-intentioned) who charged it had lost touch with aesthetic questions and with the ethical implications of writing and reading. Much of what we have in literary analysis and study at present can be seen as responsive to such critics, as in recognition that something had indeed been lost to sight. What if legal studies were to rediscover the repressed rhetorical origins of their subject-to ponder the role of rhetoric and narrative in legal decision making, for instance? What if learning to think like a lawyer was thought to require more questioning of what that really means? At the limit, should legal studies pay more attention to those critics-reaching back at least to Jean-Jacques Rousseau-who have claimed that law is founded on an act of violent usurpation and deceit? Is an awareness of such a claim, even if it can never be an awareness except under erasure, totally useless for the student or even the practitioner of law?

Peters concludes by suggesting that if "law and literature per se" does not survive, "in its end may be its beginning" (451-52). I, too, believe it is time for something of a new beginning, which means discarding the overly exposed law-and-lit rubric for something else but means also setting law in something resembling a transferential relation-in the psychoanalytic sense-to other humanistic interpretive disciplines.

\section{Peter Brooks}

University of Virginia

\section{Reply:}

In his thoughtful comment on my essay, Peter Brooks makes three central claims: a historical claim, a diagnostic claim, and a prescriptive claim. Law has repressed its ancient intimacy with rhetoric and the humanistic disciplines, claiming an institutional and educational autonomy and developing a specialized professional language untrue to its origins. Arguments for autonomy treat legal terms of art as self-definitional, "off- limits to nonlegal questioners," and thus tend to obscure the most important questions that arise in the legal sphere. To rediscover law's lost origins through the reengagement of law with the interpretive disciplines would be to break through this autonomy, to "hold the law accountable," to uncover "something that could make a difference."

Brooks offers a compelling argument for a continually renewed engagement between law and the humanities-one with which I agree politically, heuristically, even (one might say) spiritually. His own Troubling Confessions shows the payoff of such engagement at its best. But the claims that undergird his argument seem questionable. First, the historical claim. Brooks seems to draw on a familiar account, in which the institution of law gradually disavowed its dependence on the study of poetry and rhetoric, by the nineteenth century embracing a formalism that insisted on law's autonomy from other institutional modes of interpretation and argument. For Brooks, law's newfound institutional autonomy created a "professionally hermetic language" no longer in touch with "contemporary understandings of how people behave."

But was there in fact a golden past in which law was harmonious with broader traditions of rhetoric and thus "true to contemporary understandings of how people behave"? Was there a time in which law didn't assign "its actors various gatekeeping functions" in an attempt "to preserve its own nature and its autonomy"? In the sixteenth century, Cicero and Quintilian stood as ideal guides to forensic oratory, schools of rhetoric were revived as legal training grounds, and in the English Inns of Court, future lawyers were steeped in the humanist dramatic tradition. And yet Renaissance legal practice was, at the same time, characterized by what we would consider extreme formalism: its "professionally hermetic language" was incomprehensible to the uninitiated, and the inclusion of precise Latin formulas in a complaint was necessary to the success of a claim.

Conversely, law never fully embraced even the claim to autonomy. During the period that we tend to identify with the waning of the natural law tradition and the rebirth of legal formalism, Hugh Blair's 1782 Lectures on Rhetoric and Belles Lettres (published in dozens of editions) was a central 